Article

\title{
Chitosan-Zinc(II) Complexes as a Bio-Sorbent for the Adsorptive Abatement of Phosphate: Mechanism of Complexation and Assessment of Adsorption Performance
}

\author{
Maryam Roza Yazdani ${ }^{1, *}$, Elina Virolainen ${ }^{1}$, Kevin Conley ${ }^{2}$ and Riku Vahala ${ }^{1}$ \\ 1 Water and Wastewater Engineering Research Group, School of Engineering, Aalto University, P.O. Box 15200, \\ FI-00076 Aalto, Finland; elina.virolainen@gmail.com (E.V.); riku.vahala@aalto.fi (R.V.) \\ 2 COMP Centre of Excellence, Department of Applied Physics, School of Science, Aalto University, \\ FI-00076 Aalto, Finland; kevin.conley@aalto.fi \\ * Correspondence: roza.yazdani@aalto.fi; Tel.: +358-4074-2014
}

Received: 21 October 2017; Accepted: 22 December 2017; Published: 25 December 2017

\begin{abstract}
This study examines zinc(II)-chitosan complexes as a bio-sorbent for phosphate removal from aqueous solutions. The bio-sorbent is prepared and is characterized via Fourier Transform Infrared Spectroscopy (FT-IR), Scanning Electron Microscopy (SEM), and Point of Zero Charge $\left(\mathrm{pH}_{\mathrm{PZC}}\right)$-drift method. The adsorption capacity of zinc(II)-chitosan bio-sorbent is compared with those of chitosan and $\mathrm{ZnO}$-chitosan and nano-ZnO-chitosan composites. The effect of operational parameters including $\mathrm{pH}$, temperature, and competing ions are explored via adsorption batch mode. A rapid phosphate uptake is observed within the first three hours of contact time. Phosphate removal by zinc(II)-chitosan is favored when the surface charge of bio-sorbent is positive/or neutral e.g., within the $\mathrm{pH}$ range inferior or around its $\mathrm{pH}_{\mathrm{PZC}}, 7$. Phosphate abatement is enhanced with decreasing temperature. The study of background ions indicates a minor effect of chloride, whereas nitrate and sulfate show competing effect with phosphate for the adsorptive sites. The adsorption kinetics is best described with the pseudo-second-order model. Sips $\left(R^{2}>0.96\right)$ and Freundlich $\left(R^{2} \geq 0.95\right)$ models suit the adsorption isotherm. The phosphate reaction with zinc(II)-chitosan is exothermic, favorable and spontaneous. The complexation of zinc(II) and chitosan along with the corresponding mechanisms of phosphate removal are presented. This study indicates the introduction of zinc(II) ions into chitosan improves its performance towards phosphate uptake from 1.45 to $6.55 \mathrm{mg} / \mathrm{g}$ and provides fundamental information for developing bio-based materials for water remediation.
\end{abstract}

Keywords: zinc-chitosan complexes; characterization; bio-sorbent; phosphate; adsorption; mechanism; thermodynamic

\section{Introduction}

Phosphate is an important element for many natural organisms, yet in high concentrations, it can cause serious eutrophication in natural waters [1-5]. In eutrophic waters, the exceeding amount of nutrients leads to the excessive growth of plants and algae. This phenomenon reduces the dissolved oxygen in the water, which disturbs the natural balance of organisms, and causes, e.g., mass fish death $[1,6]$. Eutrophication raises the costs of water treatment, weakens the recreational use of waters and enables the growth of algal blooms that produce harmful cyanotoxins [7]. Phosphorus dissolves into natural waters from weathered rocks, peat land and forests, and it gets into the communal wastewaters through agriculture, human settlement and industry [7,8]. Miettinen et al. [8] have studied the connection of phosphorus and bacterial growth in drinking water sources and showed 
that in both surface and ground waters the addition of phosphorus strongly contributes to the growth of heterotrophic bacteria.

While the maximum phosphate concentration set by US Environmental Protection Agency (EPA) is $0.05 \mathrm{mg} / \mathrm{L}$ [9], even a concentration of $0.02 \mathrm{mg} / \mathrm{L}$ can cause major eutrophication [6]. Preserving the aquatic life from phosphate contamination requires new phosphate removal techniques $[2,10]$. The commonly practiced methods for phosphate abatement include chemical precipitation and biological removal, but they are problematic in different ways. These treatment processes usually fail to meet the standard levels set for phosphate or even to decrease it to below $10 \mathrm{mg} / \mathrm{L}$ [11]. In addition, chemical precipitation is a relatively expensive method, requiring the storage and transportation of chemical reagents and producing considerable sludge waste. Biological phosphorus removal on the other hand is relatively sensitive to water conditions, which decreases it reliability. Compared to these techniques, adsorption technology offers a simple and low cost option [7]. Recently, engineered adsorbents have attracted a great deal of attention as alternatives for common yet expensive adsorbents, e.g., activated carbon. This new type of adsorbents usually comprises two or more constituents, one of which acts as a support matrix [12]. For instance, impregnated polymers with metal oxides [3] and biomass modified with mesoporous materials [6] have previously been studied as phosphate adsorbents.

Chitosan (CTS) is a biopolymer emerging in the adsorption process and is derived from chitin, the second most plentiful natural polymer after cellulose [13-15]. It has many advantages as a bio-sorbent, such as good adsorption capacity, biodegradability, and biocompatibility [15-19]. As it is extracted from crustacean waste, it is eco-friendly and cost-effective compared to commonly employed adsorbents. Despite its good adsorption capacity for a wide range of pollutants, CTS provides a low affinity towards oxyanions mainly because of the $\mathrm{p} K_{\mathrm{a}}$ value of its electron-donor functional sites, viz. $-\mathrm{NH}_{2}$ [12]. To overcome this obstacle, the introduction of metal ions to CTS has recently been practiced [15]. Metal ions, e.g., zinc(II) [20] and copper(II) [12], are capable of forming complexes with the functional groups on the CTS chain, and consequently the complexed metal ions on the CTS structure can link with other ligands including oxyanions. Among different metal ions, zinc ( $\mathrm{Zn}$ ) can easily chelate with CTS, which has made it the focus of many studies on its application for metal ions separation [20], waste management [21], antibacterial, and medical aspects [20]. However, to date, there is limited information on $\mathrm{Zn}$ (II)-CTS complexes as adsorptive media for the removal of oxyanions like phosphate. Along with the research conducted on the antimicrobial activity, thermal degradation and pyrolysis characteristics of CTS complexation with zinc(II) $[20,21]$, a study on its application as a bio-sorbent provides deeper knowledge of the complexation and enable a better performance in the application stage towards specific goals, e.g., phosphate removal. Thus, a prospect of using Zn(II)-CTS bio-sorbent for phosphate removal was conceptualized in this study.

Here, we develop Zn(II)-CTS bio-sorbents for the removal of phosphate and study their response to adsorbent dose, phosphate concentration, solution $\mathrm{pH}$, water temperature, contact time and competing ions $\left(\mathrm{Cl}^{-}, \mathrm{NO}_{3}{ }^{-}, \mathrm{SO}_{4}{ }^{2-}\right)$ effects. The bio-sorbent dosage is optimized and compared with those of plain CTS and the composites produced from both zinc oxide $(\mathrm{ZnO})$ and nano-sized zinc oxide (nano-ZnO) embedded in CTS to indicate its better performance towards phosphate abatement. The composition, morphology and interface of the Zn(II)-CTS are characterized by Fourier transform infrared spectroscopy (FT-IR), scanning electron microscopy (SEM) and determination of the $\mathrm{pH}$ of Point of Zero Charge $\left(\mathrm{pH}_{\mathrm{PZC}}\right)$.

\section{Experimental}

\subsection{Materials}

Chitosan was supplied by Acros Organics of Thermo Fisher Scientific Inc., Geel, Belgium. The degree of deacetylation (DDA) of chitosan was $84 \pm 1 \%$ determined via acid-base titration [22,23] and its average molecular weight $\left(\overline{M_{W}}\right)$ was $153.3 \mathrm{kD}$ measured via determination of intrinsic viscosity 
as described previously $[24,25]$. Zinc oxide $(>99 \%)$ and zinc chloride $(>98 \%)$ were purchased from Merck chemicals (Darmstadt, Germany) and zinc oxide nano-powder ( $<50 \mathrm{~nm}$ particle size (BET), $>97 \%$ ) was supplied by Sigma Aldrich, Darmstadt, Germany. A stock solution with the concentration of $1000 \mathrm{mg} / \mathrm{L}$ was made via weighing an accurate amount of potassium dihydrogen phosphate $\left(\mathrm{KH}_{2} \mathrm{PO}_{4}\right)$ and dissolving it in reverse osmosis water. Different dilutions in the range of $1-15 \mathrm{mg} / \mathrm{L}$ were prepared daily before each adsorption set.

\subsection{Analysis Methods and Instruments}

The $\mathrm{pH}$ of phosphate solutions was measured according to the SFS-EN ISO 10523 (dated 2012) with WTW inoLab pH 720-meter and probe Sentix 81 Plus. The $\mathrm{pH}$ meter was calibrated before each use. Phosphate concentration was measured according to the SFS-EN ISO 15681-1 (dated 2005) via flow analysis (FIA) and spectrometric detection using tin chloride method on a FOSAS Tecator, FIAstar 5000 Analyzer and Sampler 5027.

\subsection{Adsorbent Preparation and Characterization}

This study investigated three different bio-sorbents developed from CTS and zinc compounds; $\mathrm{Zn}$ (II)-CTS, ZnO-CTS and nano-ZnO-CTS. The Zn(II)-CTS bio-sorbent was prepared as follows: dissolved CTS $(1 \mathrm{~g})$ into $0.1 \mathrm{M}$ acetic acid $(100 \mathrm{~mL})$ was agitated for $24 \mathrm{~h}$ at room temperature at a speed of $180 \mathrm{rpm}$ to achieve a thoroughly homogenous solution. Then $0.34 \mathrm{~g}$ of zinc chloride dissolved into $50 \mathrm{~mL}$ of reverse osmosis water was slowly added into the CTS solution while continuously stirring until a homogenous solution was achieved. This solution was heated to $80^{\circ} \mathrm{C}$ for $1 \mathrm{~h}$ with continuous stirring. After cooling to room temperature, the solution was pumped into $0.5 \mathrm{M} \mathrm{NaOH}$ solution ( $50 \mathrm{~mL}$ per $250 \mathrm{~mL} \mathrm{NaOH}$ ) using a syringe pump to develop the bio-sorbent in the form of beads. The product was immersed in the $\mathrm{NaOH}$ solution overnight. The final solid product was separated, rinsed with reverse osmosis water to reach neutral $\mathrm{pH}$, and dried in an oven at $25^{\circ} \mathrm{C}$. $\mathrm{ZnO}-\mathrm{CTS}$ was prepared in a similar way. The suspension of $\mathrm{ZnO}(0.2 \mathrm{~g})$ in $0.1 \mathrm{M}$ acetic acid $(100 \mathrm{~mL})$ was agitated for $24 \mathrm{~h}$ at room temperature and at the speed of $180 \mathrm{rpm}$ before mixing with the CTS. The ZnO suspension was mixed with CTS solution and agitated for another $24 \mathrm{~h}$ at room temperature. The final $\mathrm{ZnO}-\mathrm{CTS}$ was pumped into $\mathrm{NaOH}$ solution. Nano-ZnO-CTS was prepared as $\mathrm{ZnO}-\mathrm{CTS}$, but the $\mathrm{pH}$ of nano- $\mathrm{ZnO} /$ acetic acid suspension was set to 4 . The mass of zinc-compounds, $\mathrm{ZnCl}_{2}$ and $\mathrm{ZnO}$, was determined in a way that the bio-sorbent products contained an equal amount of $\mathrm{Zn}$.

The FT-IR analysis of the developed bio-sorbent was performed on a Thermo scientific Nicolet iS50 FT-IR spectrometer with a PIKE Gladi-ATR. SEM was performed with ZEISS Sigma VP (Jena, Germany) using $2 \mathrm{kV}$ acceleration voltage, detecting secondary electrons. Samples were attached to an aluminum stub using carbon tape, and sputter coated with platinum using Emitech K100X for $90 \mathrm{~s}$ and $30 \mathrm{~mA}$ coating current to prevent charging effects. The $\mathrm{pH}$ drift method was employed to determine the $\mathrm{pH}_{\text {PZC }}$ of the $\mathrm{Zn}$ (II)-CTS surface using $20 \mathrm{~mL}$ of $0.1 \mathrm{M} \mathrm{NaCl}$ in a series of solutions for which $\mathrm{pH}$ was adjusted within the range of 3 to 12 . After the initial $\mathrm{pH}$ of $\mathrm{NaCl}$ solutions was adjusted using $\mathrm{NaOH}$ and $\mathrm{HCl}, 0.01 \mathrm{~g}$ of the bio-sorbent was added to each of them and their final $\mathrm{pH}$ was measured after $24 \mathrm{~h}$. The $\mathrm{pH}_{\mathrm{PZC}}$ was noted at the $\mathrm{pH}$ where the final $\mathrm{pH}$ equals the initial $\mathrm{pH}$ [26].

\subsection{Adsorption Experiments}

All batch experiments were conducted on a shaker at the speed of $180 \mathrm{rpm}$ using $50 \mathrm{~mL}$ phosphate solutions and known amount of bio-sorbent. The $\mathrm{pH}$ of phosphate solution was set to 4 unless otherwise mentioned. After the required contact time, the solutions were filtrated with Sartorius Minisart $45 \mu \mathrm{m}$ filters and analyzed for final phosphate concentration. All experiments excluding the isotherm tests were performed at room temperature for $24 \mathrm{~h}$. The optimum adsorbent dose was determined by conducting the experiment with five different doses in range of $0.1-2 \mathrm{~g} / \mathrm{L}$. The $\mathrm{pH}$ effect was studied with adjusting the $\mathrm{pH}$ at different values between 4 and $12 \mathrm{using} \mathrm{HCl}$ and $\mathrm{NaOH}$. The effect of contact time was studied at different time intervals between $1 \mathrm{~min}$ to $48 \mathrm{~h}$. Phosphate 
solutions with initial concentration from 1 to $15 \mathrm{mg} / \mathrm{L}$ were used to study adsorption isotherm at 20, 25 , and $30{ }^{\circ} \mathrm{C} \mathrm{NO}_{3}{ }^{-}, \mathrm{SO}_{4}{ }^{2-}$ or $\mathrm{Cl}^{-}$was added to investigate the effect of competing ions on phosphate adsorption. All the adsorption experiments were carried out in two or three replicates when high standard deviation values were noticed for the removal percentage. The average of the replicates and the standard deviation values are reported accordingly. Phosphate removal and adsorption capacity were calculated with the following equations:

$$
\begin{gathered}
\text { Removal } \%=\frac{\left(C_{0}-C_{t}\right)}{C_{0}} \times 100 \\
q_{t}(\mathrm{mg} / \mathrm{g})=\frac{C_{0}-C_{t}}{m} \times V
\end{gathered}
$$

where $C_{0}(\mathrm{mg} / \mathrm{L})$ is the initial phosphate concentration, $C_{t}(\mathrm{mg} / \mathrm{L})$ the phosphate concentration at time $t, V(\mathrm{~L})$ the solution volume, and $m(\mathrm{~g})$ the adsorbent mass.

\section{Results and Discussion}

\subsection{Characterization of Zn(II)-CTS Bio-Sorbent}

\subsubsection{FT-IR Analysis}

The FT-IR spectra of Zn(II)-CTS complexes and plain CTS were analyzed to determine the compositional differences as seen in Figure 1. The broad characteristic peak in the region $3100-3600 \mathrm{~cm}^{-1}$, related to the stretching vibration of $-\mathrm{NH}_{2}$ and $-\mathrm{OH}$ groups of CTS, are shifted to lower wavenumbers on the spectrum of $\mathrm{Zn}$ (II)-CTS. The O-H stretching band at $3740 \mathrm{~cm}^{-1}$ on the spectrum of CTS has moved to $3760 \mathrm{~cm}^{-1}$ with a lower intensity on the spectrum of $\mathrm{Zn}$ (II)-CTS. The peak at $1640 \mathrm{~cm}^{-1}$, related to the $-\mathrm{NH}_{2}$ bending vibration of CTS, is shifted to higher frequencies $\left(1660 \mathrm{~cm}^{-1}\right)$ for $\mathrm{Zn}$ (II)-CTS indicating the $-\mathrm{NH}_{2}$ and $-\mathrm{OH}$ groups on the CTS backbone have complexed with $\mathrm{Zn}$ (II). The band at $1090 \mathrm{~cm}^{-1}$ representing the secondary -OH of CTS is moved to $1080 \mathrm{~cm}^{-1}$ along with a higher intensity on the spectrum of $\mathrm{Zn}$ (II)-CTS. The band shift from $1090 \mathrm{~cm}^{-1}$ to $1080 \mathrm{~cm}^{-1}$ is characteristic of the coordination of $-\mathrm{OH}$ with $\mathrm{Zn}$ [20]. The peaks at 2920, 2880, 1600, 1380, 1080 and $620 \mathrm{~cm}^{-1}$ are assigned to methylene $\mathrm{C}-\mathrm{H}_{2}$ and methyl $\mathrm{C}-\mathrm{H}$ stretching vibrations, $\mathrm{N}-\mathrm{H}$ groups, $\mathrm{C}-\mathrm{H}$ asymmetric bending, $\mathrm{C}-\mathrm{O}$ alcohol stretching and $\mathrm{O}-\mathrm{H}$ bending (out-of-plane), respectively. The vibrational bands at 1780 and $898 \mathrm{~cm}^{-1}$ correspond to the $\mathrm{C}=\mathrm{O}$ band and glucopyranose ring of CTS, respectively. The peak at $620 \mathrm{~cm}^{-1}$, assigned to the hydroxyl groups of CTS, has moved to $650 \mathrm{~cm}^{-1}$ on the spectrum of $\mathrm{Zn}$ (II)-CTS. Moreover, the appearance of peaks around 450 and $570 \mathrm{~cm}^{-1}$ on the spectrum of $\mathrm{Zn}(\mathrm{II})-\mathrm{CTS}$ are characteristics of the stretching vibrations of $\mathrm{Zn}-\mathrm{O}$ and $\mathrm{Zn}-\mathrm{N}[20,27]$.

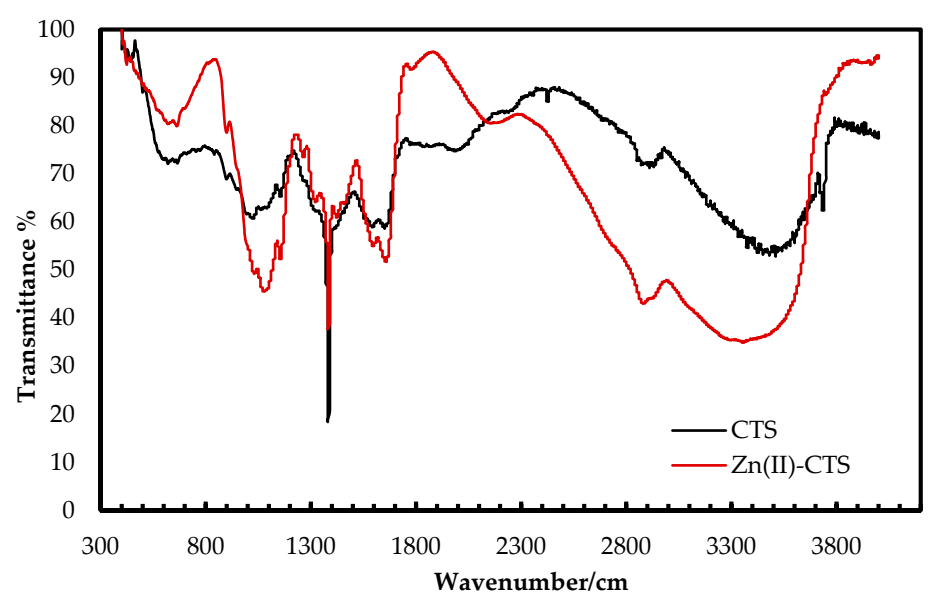

Figure 1. Fourier transform infrared (FT-IR) spectra of CTS and Zn(II)-CTS. 


\subsubsection{SEM Analysis}

The surface morphology of $\mathrm{Zn}(\mathrm{II})-\mathrm{CTS}$ was studied via scanning electron microscopy. Figure 2 indicates that the developed $\mathrm{Zn}$ (II)-CTS bio-sorbent shows an irregular and rough surface including micro-pores and small fractures, into which the oxyanions can penetrate and better access the internal functional adsorptive sites. Porosity enables the second phase adsorption according to the intra-particle diffusion theory, which is further discussed in kinetics modelling. The bio-sorbent particles have an irregular bead-like shape (granular) as seen in Figure 2.

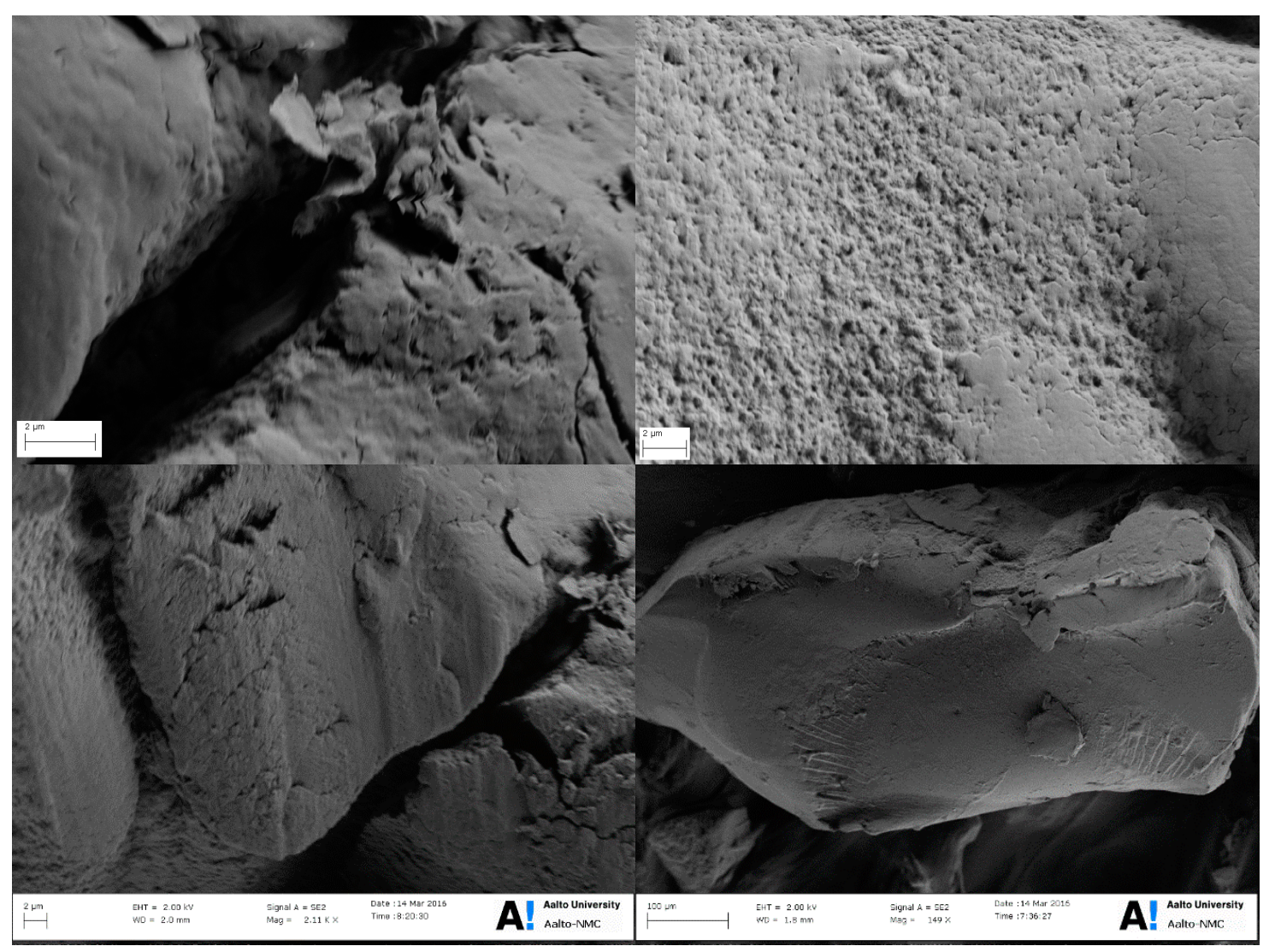

Figure 2. Scanning electron microscopy (SEM) images of Zn(II)-CTS beads at different magnifications $(2 \mu \mathrm{m}$ and $100 \mu \mathrm{m})$.

\subsubsection{Determination of $\mathrm{pH}_{\mathrm{PZC}}$}

Point of zero charge plays a key role in the surface science of environmental interfaces, where it indicates how easily adsorptive materials are able to adsorb the ions of target pollutants. The $\mathrm{pH}_{\mathrm{PZC}}$ is the $\mathrm{pH}$ when the charge on the adsorbent surface is zero. Figure 3a depicts the results of the $\mathrm{pH}_{\text {PZC }}$ determination via drift method ( $\mathrm{NaCl}$ solutions). The $\mathrm{pH}_{\mathrm{PZC}}$ of $\mathrm{Zn}$ (II)-CTS bio-sorbent was determined to be approximately 7 , which is a reasonable $\mathrm{pH}_{\mathrm{PZC}}$, given that the $\mathrm{p} K_{\mathrm{a}}$ of CTS ranges from 6.3 to 7.2. At solution $\mathrm{pH}$ above the $\mathrm{pH}_{\mathrm{PZC}}$, the surface of the bio-sorbent is negatively charged, whereas at $\mathrm{pH}$ values below $\mathrm{pH}_{\mathrm{PZC}}$, the surface becomes positively charged and oxyanions adsorption happens due to electrostatic interaction of anions with the positively charged surface of the bio-sorbent. Hence, there is an increase in phosphate adsorption when the solution $\mathrm{pH}$ is lower than $\mathrm{pH}_{\mathrm{PZC}}[3,26]$. A similar experimental set was conducted with $\mathrm{PO}_{4}{ }^{3-}$ solutions (Figure $3 \mathrm{~b}$ ). The final $\mathrm{pH}$ converged to around 7 when the initial $\mathrm{pH}$ was set from 4 to 11 . For the solution with the initial $\mathrm{pH}$ of 3 , the final $\mathrm{pH}$ remained below the $\mathrm{pH}_{\mathrm{PZC}}$ which can be due to the abundant $\mathrm{H}^{+}$ions preventing the $\mathrm{pH}$ raise induced by the bio-sorbent. For the sample with initial $\mathrm{pH}$ of 12 , the final $\mathrm{pH}$ was 10.1 , higher than 
$\mathrm{pH}_{\mathrm{PZC}}$, which happens due to the excessive amount of $\mathrm{OH}^{-}$ions. Above $\mathrm{pH}_{\mathrm{PZC}}$, the adsorption of anions is hindered by the negatively charged surface of $\mathrm{Zn}(\mathrm{II})-\mathrm{CTS}$.

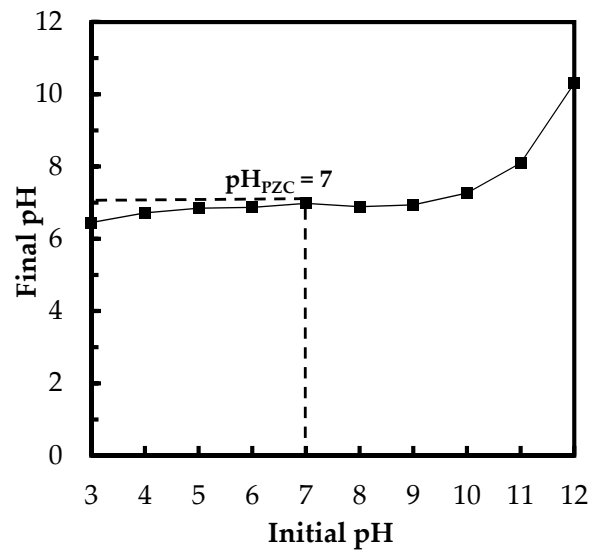

(a)

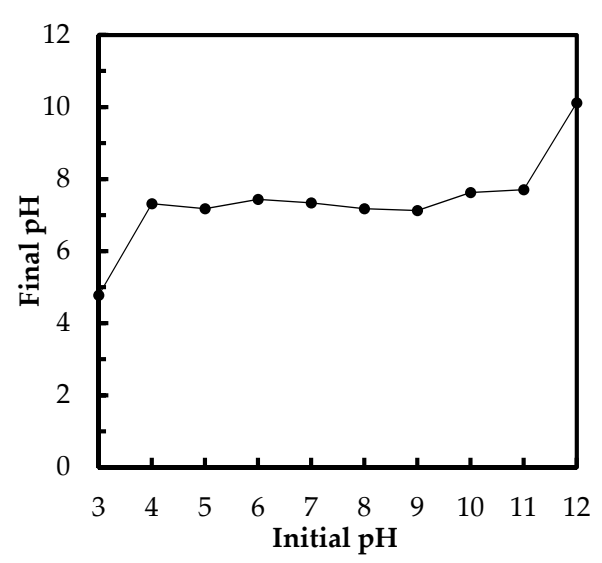

(b)

Figure 3. (a) The determination of point of zero charge $\left(\mathrm{pH}_{\mathrm{PZC}}\right)$ using $0.1 \mathrm{M} \mathrm{NaCl}$ solutions (drift method); and (b) change of $\mathrm{pH}$ in the $5 \mathrm{mg} / \mathrm{L} \mathrm{PO}_{4}{ }^{3-} / \mathrm{Zn}$ (II)-CTS solutions (Experimental conditions: $0.01 \mathrm{~g}$ of $\mathrm{Zn}(\mathrm{II})-\mathrm{CTS} ; 20 \mathrm{~mL}$ solution volume; contact time $24 \mathrm{~h}$ ).

\subsection{Phosphate Adsorption Studies}

\subsubsection{Effect of Bio-Sorbent Dose}

Adsorbent dose was optimized for three zinc compound-CTS bio-sorbents, Zn(II)-CTS, ZnO-CTS and nano-ZnO-CTS, and additionally for a plain CTS sample. Different adsorbent doses varying between 0.1 to $2 \mathrm{~g} / \mathrm{L}$ were studied. Similar trends in the results of phosphate removal percentage and adsorption capacity $(\mathrm{mg} / \mathrm{g})$ were observed for all three composites. As the amount of absorbent was increased, the removal percentage increases (Figure 4). This is because the growing adsorption surface area increases the active adsorptive sites on the surface. With the adsorbent dose of $0.1 \mathrm{~g} / \mathrm{L}$, all three bio-sorbents reached a removal percentage in the range of $19.7-21.7 \%$. After this, the removal efficiency of nano-ZnO-CTS grew less than those of $\mathrm{ZnO}-\mathrm{CTS}$ and $\mathrm{Zn}$ (II)-CTS. At the maximum adsorbent dose, $2 \mathrm{~g} / \mathrm{L}$, the removal percentage of nano-ZnO-CTS was $71.5 \%$ whereas for $\mathrm{ZnO}-\mathrm{CTS}$ and $\mathrm{Zn}$ (II)-CTS $97.75 \%$ and $94.65 \%$, respectively. When comparing the nano-ZnO-CTS to the other two bio-sorbets, the lower adsorption performance, e.g., removal percentages and corresponding capacities in Figure 4, along with higher standard deviations may be caused by the aggregated nano $\mathrm{ZnO}$ particles in the nano-ZnO-CTS beads. In comparison, the plain CTS sample (Figure 4a) proved to be relatively unsuccessful with only $10 \%$ average removal, which is mainly due to the $\mathrm{p} K_{\mathrm{a}}$ value of its electron-donor functional groups, viz. $-\mathrm{NH}_{2}$. The formation of new binding sites by $\mathrm{Zn}$ (II) ions within the CTS matrix is followed by the coordination of the phosphate anions to zinc(II). These chelating sites are unavailable to phosphate anions in the plain CTS, proved by the low performance of CTS in Figure 4. This observation confirms the improving effect of zinc(II) complexes in the adsorption performance of CTS towards phosphate oxyanions.

As seen in Figure $4 \mathrm{~b}$, the adsorption capacity $q_{t}$ decreases for all four adsorbents with increasing dose. The capacity decreased for ZnO-CTS from 12.37 to $2.43 \mathrm{mg} / \mathrm{g}$, for $\mathrm{Zn}$ (II)-CTS from 10.99 to $2.37 \mathrm{mg} / \mathrm{g}$, and for nano-ZnO-CTS from 10.21 to $1.78 \mathrm{mg} / \mathrm{g}$. This reduction can happen due to (I) a gap in the flux of phosphate concentration gradient between the concentrations in the liquid phase and on the solid surface, causing the amount of phosphate adsorbed onto the unit weight of adsorbent to decrease with the increasing dose [28], and/or (II) the increase in the adsorbent dose for a given amount of phosphate in the solution results in the unsaturation of adsorbent sites. In addition, more 
adsorptive sites become occupied, hence creating an increasing repulsion between the molecules in the solution and adsorbed on the surface [4].

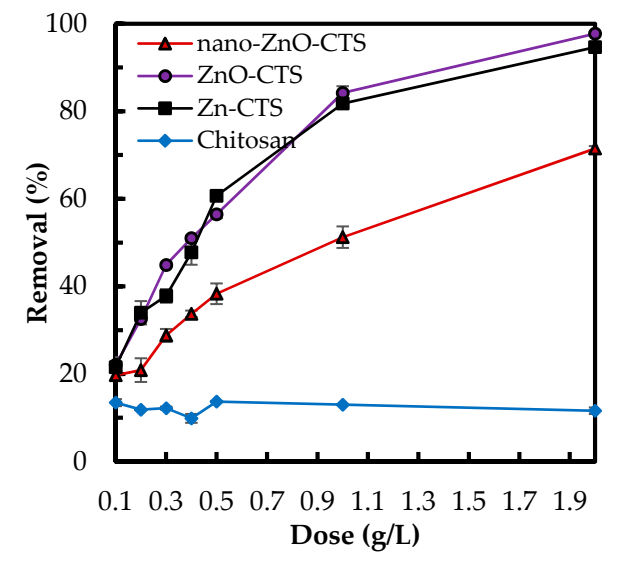

(a)

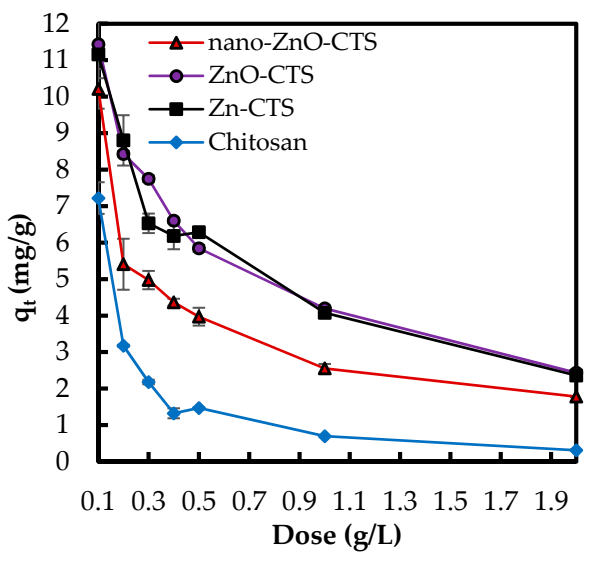

(b)

Figure 4. (a) Effect of adsorbent dose on (a) phosphate removal percentage; and (b) phosphate adsorption capacity (mg/g) (Experimental conditions: $5 \mathrm{mg} / \mathrm{L}$ phosphate concentration; natural $\mathrm{pH}$; $50 \mathrm{~mL}$ solution).

The bio-sorbent/liquid ratio was set to $0.5 \mathrm{~g} / \mathrm{L}$ for the rest of adsorption studies to account for the balance between the lower removal percentage at lower dosage and lower adsorption capacity $(q)$ at higher dosage.

\subsubsection{Effect of $\mathrm{pH}$}

The role of $\mathrm{pH}$ in phosphate uptake by the developed $\mathrm{Zn}$ (II)-CTS bio-sorbent was studied in five different $\mathrm{pH}$ values. The binding of phosphate oxyanions to the bio-sorbent occurred more efficiently in acidic medium, as seen in Figure 5. This enhancement of the removal percentage is consistent with previous studies of adsorptive abatement of phosphate [3].

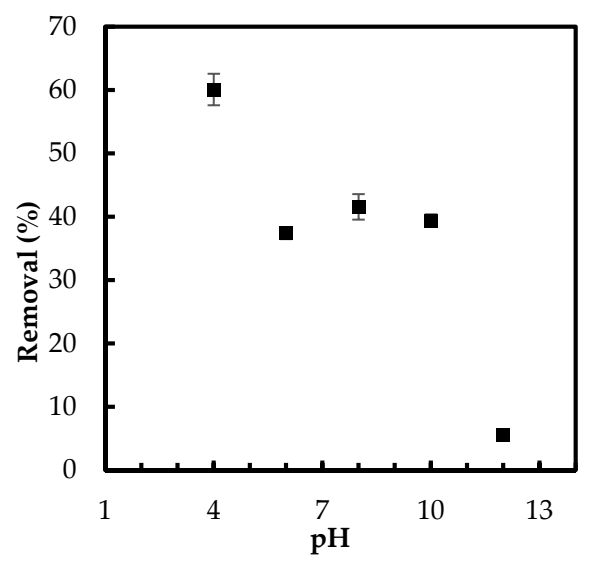

Figure 5. Effect of $\mathrm{pH}$ on phosphate removal by $\mathrm{Zn}$ (II)-CTS complex (Experimental conditions: $0.5 \mathrm{~g} / \mathrm{L}$ adsorbent dose; $5 \mathrm{mg} / \mathrm{L}$ initial phosphate concentration).

The decrease in the phosphate adsorption onto $\mathrm{Zn}(\mathrm{II})-\mathrm{CTS}$ by shifting $\mathrm{pH}$ from acidic to basic conditions can be attributed to the change in the distribution of phosphate species $\left(\mathrm{H}_{2} \mathrm{PO}_{4}{ }^{-}, \mathrm{HPO}_{4}{ }^{2-}\right.$, and $\mathrm{PO}_{4}{ }^{3-}$ ) and the decrease in surface protonation of the bio-sorbent. Additionally, in the basic solution, the hydroxyl ions may compete with phosphate adsorption [4]. High $\mathrm{pH}$ alter the aqueous 
form of phosphate species from $\mathrm{H}_{2} \mathrm{PO}_{4}{ }^{-}$to $\mathrm{HPO}_{4}{ }^{2-}$. The latter species is more resistant to the uptake by the surface hydroxyl groups. The limited adsorption at higher $\mathrm{pH}$ can also be caused by the excess amount of $\mathrm{OH}^{-}$ions and deprotonation of $\mathrm{Zn}$ (II)-CTS surface, leading to a decrease in the interaction between the surface of $\mathrm{Zn}$ (II)-CTS and phosphate anions [28]. On the other hand, lower acidic condition protonates the surface functional groups of Zn(II)-CTS complexes, as discussed in the section related to $\mathrm{pH}_{\mathrm{PZC}}$, resulting in higher phosphate uptake due to the electrostatic attraction. As showed in Figure $3 \mathrm{~b}$, there is a shift in the final $\mathrm{pH}$ of the phosphate solutions from the initial $\mathrm{pH}$. The solution with an initial $\mathrm{pH}$ of 12 , for instance, had a final $\mathrm{pH}$ of 10 , which is higher than $\mathrm{pH}_{\mathrm{PZC}}$ of the bio-sorbent. The surface is negatively charged above $\mathrm{pH}_{\mathrm{PZC}}$ and consequently repels phosphate oxyanions. For the initial $\mathrm{pH}$ ranging 6-10, the final $\mathrm{pH}$ of the solutions shifted to around $\mathrm{pH}_{\mathrm{PZC}}, 7$, resulting in a neutral surface of the bio-sorbent. Therefore, the anions of phosphate were able to easily move to the surface and finally chelate with the $\mathrm{Zn}(\mathrm{II})$ sites of the bio-sorbent. Because the surface is neutral between $\mathrm{pH} 6$ and 8 (Figure 5), the slightly higher removal at $\mathrm{pH} 8$ may be due to more readily accessible $\mathrm{Zn}(\mathrm{II})$ adsorptive sites. Furthermore, considering the kinetics of transport into a charged pore, salt will screen the charges in the pores allowing for faster transport into the pores. Therefore, there is a faster/better adsorption. The solution with initial $\mathrm{pH} 4$ showed the highest phosphate removal implying a positive surface charge of the bio-sorbent, which favored the oxyanion removal.

\subsubsection{Adsorption Kinetics}

When it comes to the economical design of an adsorption process, the time for the system to reach equilibrium is an essential parameter [4]. The contact time was studied within 13 different time intervals from $1 \mathrm{~min}$ up to $48 \mathrm{~h}$ for three different phosphate concentrations $(1,5,10 \mathrm{mg} / \mathrm{L})$. The adsorption equilibrium and maximum capacities of phosphate adsorption were obtained within $180 \mathrm{~min}$. All three sets of experiments increased the removal percentage during the first $180 \mathrm{~min}$, which was followed by a plateau. The concentration gradient of phosphate in the solution and the existence of the higher number of available active sites on the surface drive the increase in adsorption. The maximum phosphate removal percentages for 10,5 and $1 \mathrm{mg} / \mathrm{L}$ were $54.84 \%, 75.70 \%$ and $97.63 \%$, respectively (Figure 6). The corresponding adsorption capacity $(\mathrm{mg} / \mathrm{g}$ ) for those percentages were $10.99,7.39$ and $2.00 \mathrm{mg} / \mathrm{g}$, respectively. The decrease in removal by increasing concentration from 1 to $10 \mathrm{mg} / \mathrm{L}$ is expected as there are more molecules of adsorbate in the solution when the concentration increases so that the denominator of the percentage is greatly increased, resulting in a lower percentage. Furthermore, the adsorbent surface has a saturation stage (Langmuir monolayer coverage $5.33 \mathrm{mg} / \mathrm{g}$ discussed in the adsorption isotherm section). Once the surface is covered, the adsorption kinetics will change and the removal percent will decrease.

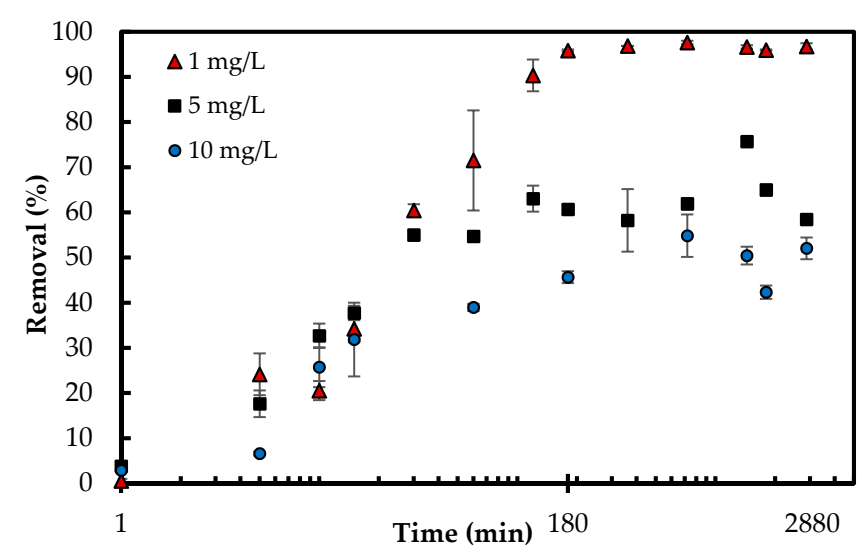

Figure 6. Effect of contact time on phosphate removal percentage (Experimental conditions: $0.5 \mathrm{~g} / \mathrm{L}$ $\mathrm{Zn}(\mathrm{II})-\mathrm{CTS}$ dose; 1, 5 and $10 \mathrm{mg} / \mathrm{L}$ initial phosphate concentration; $\mathrm{pH}$ 4). 
The pseudo-first-order [29] and pseudo-second-order [30] kinetic models were employed to gather information on the adsorption dynamics [31]; the equations presented in Table 1. The applicability of the models via linear regression can be estimated by presenting the experimental data in plots: a linear plot of $\log \left(q_{e}-q_{t}\right)$ against $t$ indicates better fit with pseudo-first-order model while a linear plot of $t / q_{t}$ versus t presents better fit with pseudo-second-order model (Figure S1) [7]. The experimental $q_{t}$ and the corresponding theoretical values, which were obtained by inserting the linearized parameters from Table 1 in the kinetic models are displayed in Figure S2. The kinetic constants and the linear $R^{2}$ values from the models are compiled in Table 1 . The linear $R^{2}$ values corresponding to pseudo-first-order model all fall under 0.8 whereas the $R^{2}$ values corresponding to pseudo-second-order model are all above 0.99 (Table 1 and Figure S1). This suggests that the pseudo-second-order is more applicable than pseudo-first-order model in presenting the kinetics of phosphate adsorption onto $\mathrm{Zn}$ (II)-CTS.

Table 1. Calculated parameters for kinetic models via linear and nonlinear regression.

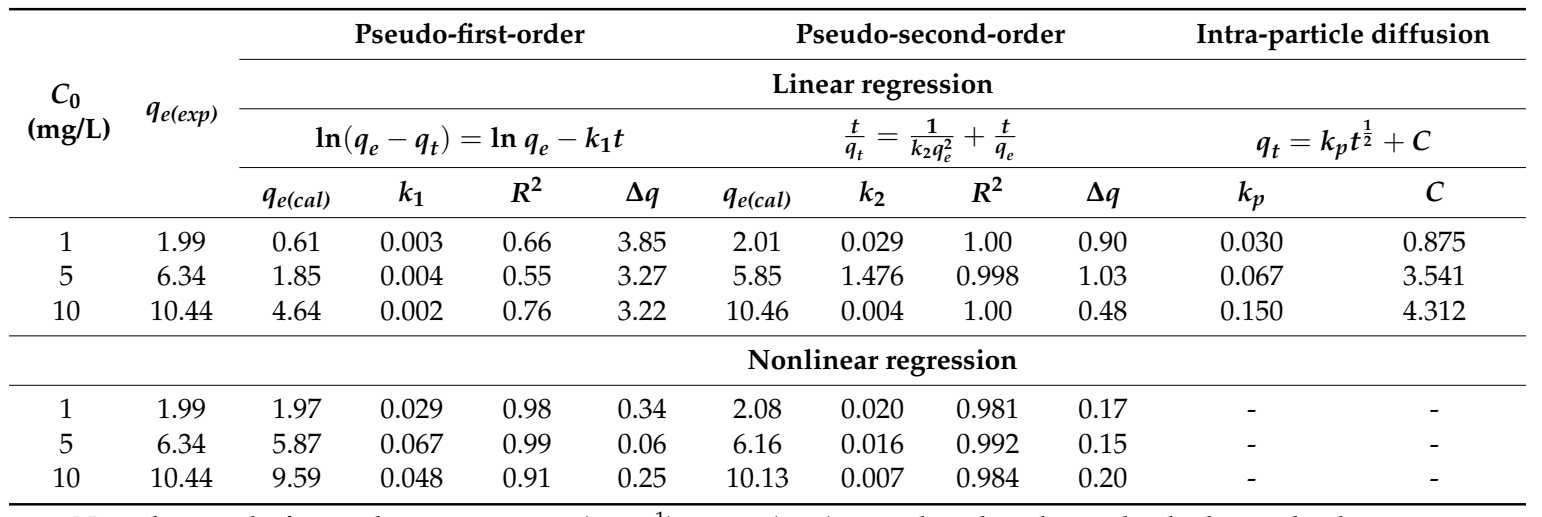

Note: $k_{1}$ pseudo-first-order rate constant $\left(\mathrm{min}^{-1}\right) ; t$ time $(\mathrm{min}) ; q_{e}$ and $q_{t}$ phosphate adsorbed per adsorbent mass at equilibrium and at time $t(\mathrm{mg} / \mathrm{g}) ; k_{2}$ pseudo-second-order rate constant $(\mathrm{g} / \mathrm{mg} \cdot \mathrm{min}) ; k_{p}$ intraparticle diffusion constant $\left(\mathrm{mg} / \mathrm{g} \cdot \mathrm{min}^{1 / 2}\right) ; C$ boundary layer thickness constant $(\mathrm{mg} / \mathrm{g})$.

In addition, the normalized standard deviation $\Delta q$ is determined for quantitative comparison of the model applicability, given in Table 1.

$$
\Delta q=\sqrt{\frac{\sum\left[\left(q_{\exp }-q_{c a l}\right) / q_{\exp }\right]^{2}}{n-1}}
$$

where $n$ is the number of data points. Even though the linear regression provided high $R^{2}$ values, the corresponding $\Delta q$ values (Table 1) and Figure S2 indicate a poor performance of linear regression for determination of best fitting kinetic models. Therefore, a nonlinear regression has been employed to further explore the kinetic data and confirm the best fitting kinetic model (Table 1 and Figure 7). The coefficient of determination $R^{2}$ is employed to find out the best-fitting model via nonlinear regression.

$$
R^{2}=\frac{\sum_{i=1}^{p}\left(q_{\text {exp }}-\overline{q_{\text {calc }}}\right)^{2}}{\sum_{i=1}^{p}\left(q_{\text {exp }}-\overline{q_{\text {calc }}}\right)^{2}+\sum_{i=1}^{p}\left(q_{\text {exp }}+\overline{q_{\text {calc }}}\right)^{2}}
$$

where $\overline{q_{c a l c}}$ is the average of $q_{\text {calc }}$. The experimental data $\left(q_{\text {exp }}\right)$ aligned better with the theoretical data $\left(q_{c a l}\right)$ obtained by nonlinear regression of pseudo-second-order model (Figure 7) that is consistent with corresponding nonlinear $R^{2}$ and $\Delta q$ values. This indicates that the adsorption may be involved in chemisorption [6] and is influenced by the characteristics of both the adsorbent and adsorbate [28]. The phosphate adsorption also followed pseudo-second-order kinetics in other studies [3-5,32]. 


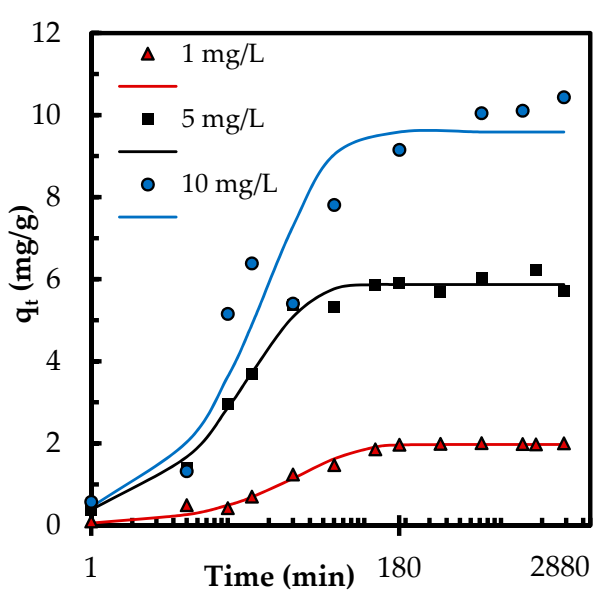

(a)

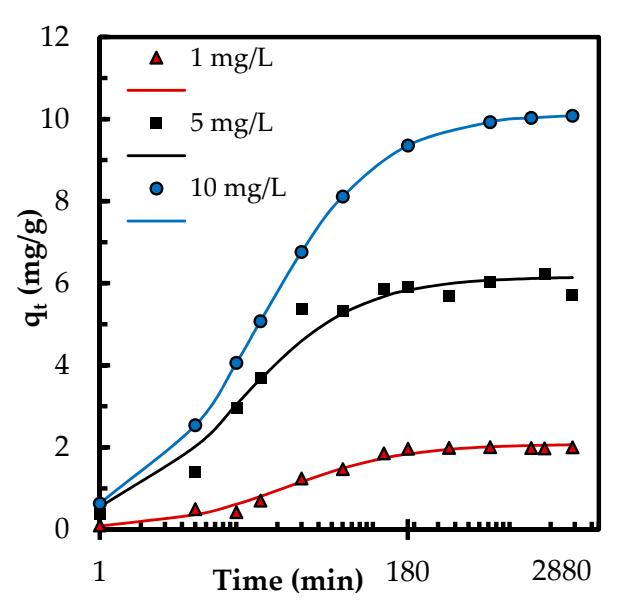

(b)

Figure 7. (a) Theoretical $q_{t}$ (lines) by pseudo-first-order kinetic model; and (b) theoretical $q_{t}$ (lines) by pseudo-second-order kinetic model determined by nonlinear regression compared to experimental $q_{t}$ (markers).

Intra-particle diffusion mechanism was explored according to Weber and Morris model [33] using the equation given in Table 1 . In this model, the $\mathrm{C}$ constant represents the thickness of the boundary layer [7]. The results are compiled in Table 1. The multi-linear plot of $q_{t}$ versus $t^{1 / 2}$ (Figure 8) suggests several phases occur in the adsorption process and the pore diffusion is not the only rate-limiting stage $[7,33]$. During the first phase, the phosphate oxyanions are transferred onto the surface of $\mathrm{Zn}$ (II)-CTS complexes from the solution (boundary layer phase). During the second and slower phase, the anions are transported to the pores of $\mathrm{Zn}$ (II)-CTS particles where intra-particle diffusion is the rate-limiting step. As discussed in earlier sections, the surface charge of the bio-sorbent is mainly of positive or neutral charge in the studied $\mathrm{pH}$ range, therefore the transfer of phosphate anions from the solution to the surface of the bio-sorbent can take place faster and more easily. In some cases, there is a third and final stage which can be considered as the equilibrium phase in which intra-particle diffusion starts slowing down because of the very dilute concentration of adsorbate remained in the liquid phase [34,35]. In Figure 8, the first two phases of adsorption are visible.

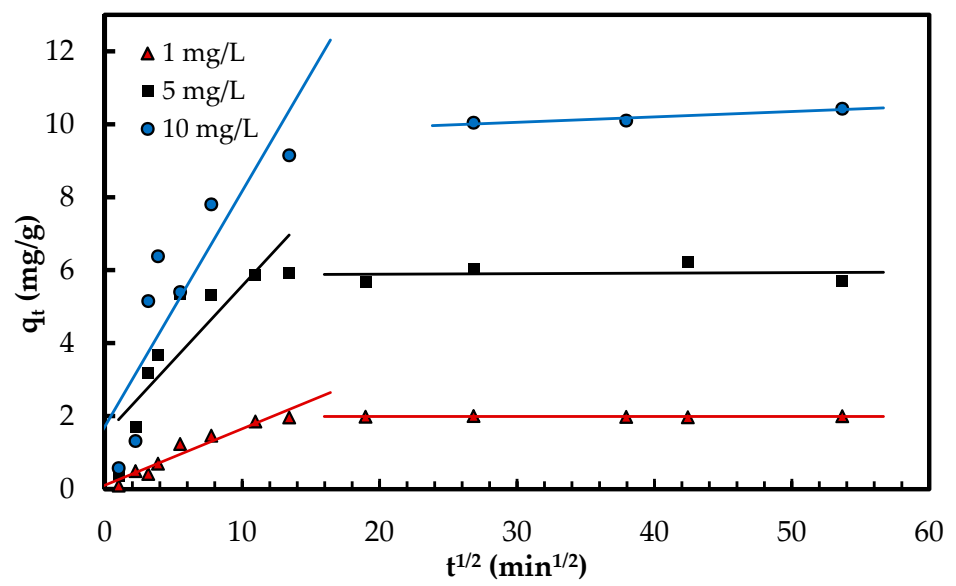

Figure 8. Phosphate adsorption steps onto Zn(II)-CTS bio-sorbent determined with the intra-particle diffusion model. 


\subsubsection{Adsorption Isotherm}

The isotherm tests were conducted in five phosphate concentrations of 1,2,5, 10 and $15 \mathrm{mg} / \mathrm{L}$ at 20, 25 , and $30^{\circ} \mathrm{C}$. When comparing the results of varying temperature, both the removal percentage and the adsorption capacity improved with a decrease in temperature (Figure 9). For instance, at concentration $5 \mathrm{mg} / \mathrm{L}$, adsorption capacity increased from 3.9 to $5 \mathrm{mg} / \mathrm{g}$ and the removal percentage increased from $36 \%$ to $47.4 \%$ with decreasing temperature from 30 to $20^{\circ} \mathrm{C}$, respectively. This indicates that lower temperatures favor the adsorption process. When comparing the results at a constant temperature, while the adsorption capacity increased with increasing $\mathrm{PO}_{4}{ }^{3-}$ concentration, the removal percentage diminished. For instance, at $20{ }^{\circ} \mathrm{C}$, adsorption capacity increased from 1.8 to $7.2 \mathrm{mg} / \mathrm{g}$ while the removal percentage decreased from $91 \%$ to $23 \%$ with increasing phosphate concentration from 1 to $15 \mathrm{~g} / \mathrm{L}$, respectively. Lower removal percentage at higher phosphate concentrations can be caused from the saturation of adsorptive sites. The equilibrium data were examined with Langmuir, Freundlich, and Sips isotherms. While the Langmuir model hypothesizes a homogenous monolayer adsorption without molecule interaction, Freundlich isotherm assumes multilayer adsorption with molecule interaction [36]. The Sips isotherm, combining the basics of Langmuir and Freundlich isotherms, represents systems where an adsorbed molecule can be involved with more than one adsorptive site [15]. At lower adsorbate concentrations, this model turns to a Freundlich model, while, at higher concentrations, it gives the monolayer coverage characteristic of Langmuir isotherm. Giles et al. [37] have presented four main types of capacity curves, C, L, H and S. Herein, the adsorption capacity curve resembled the " $\mathrm{L}$ " isotherm without a strict plateau, i.e., it does not reach a point of limited adsorption capacity. For the "L" capacity curve, the Freundlich isotherm was found to be the most suitable [37].

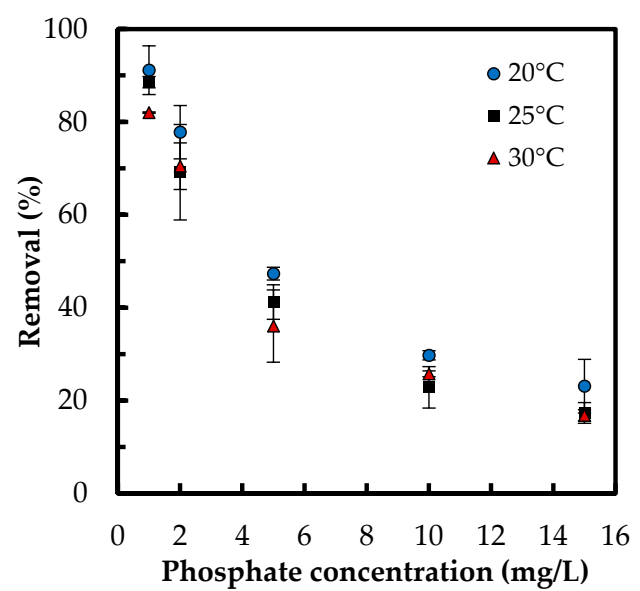

(a)

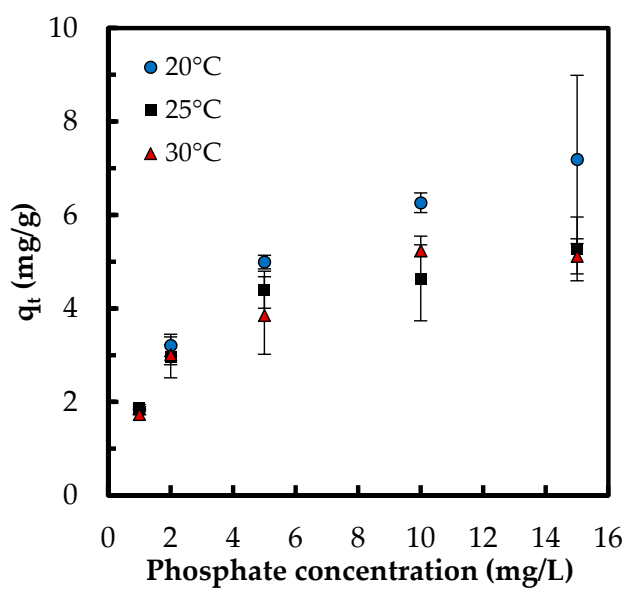

(b)

Figure 9. Effect of temperature on: (a) phosphate removal percentage; and (b) adsorption capacity (mg/g) (Experimental conditions: $0.5 \mathrm{~g} / \mathrm{L} \mathrm{Zn(II)-CTS} \mathrm{dose;} \mathrm{pH} 4 ; 24$ h contact time).

The calculated parameters via linear regression along with the linearized isotherm equations are compiled in Table 2. The unitless Langmuir separation factor $R_{L}$ shows the favorability of the adsorption; the values between 1 and 0 suggest favorable adsorption [7]. The linear $R^{2}$ values for Langmuir model were slightly higher than those of Freundlich model. However, the calculated values for $q_{e}$ with linearized Freundlich isotherm showed a better fit with experimental $q_{e}(\Delta q$ values in Table 2 and Figure S3).

$$
R_{L}=\frac{1}{1+K_{L} C_{0}}
$$


Table 2. Calculated isotherm parameters via linear regression.

\begin{tabular}{|c|c|c|c|c|c|c|c|c|c|}
\hline \multirow{3}{*}{$T(\mathrm{~K})$} & \multicolumn{5}{|c|}{ Langmuir } & \multicolumn{4}{|c|}{ Freundlich } \\
\hline & \multicolumn{4}{|c|}{$\frac{C_{e}}{\boldsymbol{q}_{e}}=\frac{1}{\boldsymbol{q}_{\max }} C_{e}+\frac{1}{K_{L} \boldsymbol{q}_{\max }}$} & & \multicolumn{4}{|c|}{$\log q_{e}=\log K_{F}+\frac{1}{n} \log C_{e}$} \\
\hline & $q_{\max }$ & $K_{L}$ & $R_{L}$ & $R^{2}$ & $\Delta q$ & $K_{F}$ & $1 / n$ & $R^{2}$ & $\Delta q$ \\
\hline 293 & 7.37 & 1.32 & $0.05-0.43$ & 0.99 & 0.31 & 3.72 & 0.27 & 0.99 & 0.04 \\
\hline 298 & 5.33 & 1.85 & $0.03-0.34$ & 0.99 & 0.24 & 3.12 & 0.22 & 0.98 & 0.06 \\
\hline 303 & 5.40 & 1.56 & $0.04-0.38$ & 0.99 & 0.18 & 2.92 & 0.25 & 0.95 & 0.1 \\
\hline
\end{tabular}

Note: $C_{e}$ equilibrium phosphate concentration; $K_{L}$ Langmuir thermodynamic constant $(\mathrm{L} / \mathrm{mg}) ; R_{L}$ Langmuir separation factor; $q_{e}$ adsorption capacity in equilibrium; $q_{\max }$ calculated maximum adsorption capacity at each temperature; $K_{F}$ Freundlich thermodynamic constant $\left((\mathrm{mg} / \mathrm{g}) \cdot(\mathrm{L} / \mathrm{mg})^{1 / n}\right) ; 1 / n$ Freundlich's intensity factor.

Even though linear regression is frequently employed to determine the best fitting isotherm, the error structure can alter upon linearizing the nonlinear equations. Based on the way the isotherm is linearized, the error distribution may change for either the worse or the better. Nonlinear regression is more suitable for the determination of the isotherm parameters, which can prevent such errors. Furthermore, the linear regression is inapplicable for isotherms with more than two adjustable parameters, e.g., Sips [15]. Therefore, the isotherm parameters were also determined by nonlinear regression. For nonlinear method, a trial and error approach was employed by minimizing the error between experimental data and calculated values. The calculated isotherm parameters via nonlinear regression are compiled in Table 3. The nonlinear $R^{2}$ values for Freundlich isotherm via nonlinear regression were higher when compared with those of the linear $R^{2}$ values. This indicates the error distribution altered to the worse while fitting the experimental data in linearized Freundlich model. The Freundlich $R^{2}$ values were higher when compared with those of Langmuir $R^{2}$ values (nonlinear regression). Figure 10 depicts the experimental $q_{e}$ and the predicted $q_{c a l c}$ by the isotherm models via nonlinear modeling. The $\Delta q$ values based on Freundlich model were also lower compared with those of Langmuir isotherm via both linear and nonlinear regressions. Figure 10 and Table 3 clearly suggest that the adsorption isotherm of phosphate onto Zn(II)-CTS is better fit to a Freundlich model than a Langmuir model, yet this is the Sips model indicating the best fit. The fitting of the experimental data to the Sips model indicates that phosphate adsorption takes place on homogeneous-heterogeneous surface of the bio-sorbent.

Table 3. Calculated isotherm parameters via nonlinear regression.

\begin{tabular}{|c|c|c|c|c|c|c|c|c|c|c|c|c|c|}
\hline \multirow{3}{*}{$T(\mathrm{~K})$} & \multicolumn{4}{|c|}{ Langmuir } & \multicolumn{4}{|c|}{ Freundlich } & \multicolumn{5}{|c|}{ Sips } \\
\hline & \multicolumn{4}{|c|}{$q_{e}=\frac{q_{\max } K_{L} C_{e}}{1+K_{L} C_{e}}$} & \multicolumn{4}{|c|}{$q_{e}=K_{F} C_{e}^{\frac{1}{n}}$} & \multicolumn{5}{|c|}{$q_{e}=\frac{q_{s} K_{s} C_{e}^{n s}}{1+K_{S} C_{e}^{n s}}$} \\
\hline & $q_{\max }$ & $K_{L}$ & $R^{2}$ & $\Delta q$ & $K_{F}$ & $1 / n$ & $R^{2}$ & $\Delta q$ & $q_{s}$ & $K_{s}$ & $n_{S}$ & $R^{2}$ & $\Delta q$ \\
\hline 293 & 6.75 & 2.11 & 0.92 & 0.23 & 3.77 & 0.26 & 1.00 & 0.05 & 17.1 & 0.29 & 0.34 & 1.00 & 0.03 \\
\hline 298 & 4.98 & 3.19 & 0.93 & 0.16 & 3.17 & 0.20 & 0.97 & 0.07 & 6.94 & 0.94 & 0.33 & 0.99 & 0.04 \\
\hline 303 & 5.12 & 2.25 & 0.93 & 0.11 & 3.01 & 0.23 & 0.95 & 0.12 & 7.26 & 0.77 & 0.48 & 0.96 & 0.08 \\
\hline
\end{tabular}

Note: $q_{s}$ Sips maximum capacity $(\mathrm{mg} / \mathrm{g}) ; K_{S}$ Sips equilibrium constant $\left((\mathrm{L} / \mathrm{mg})^{n s}\right) ; n_{S}$ Sips exponent. 


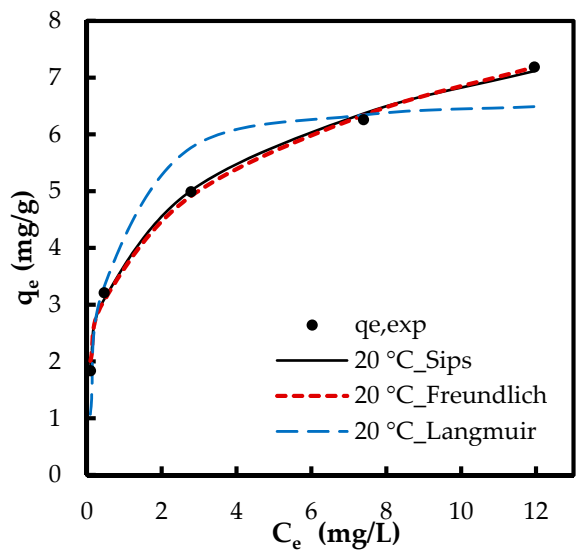

(a)

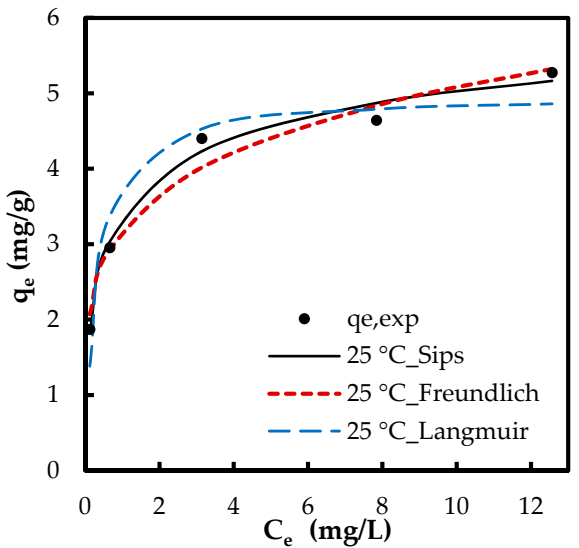

(b)

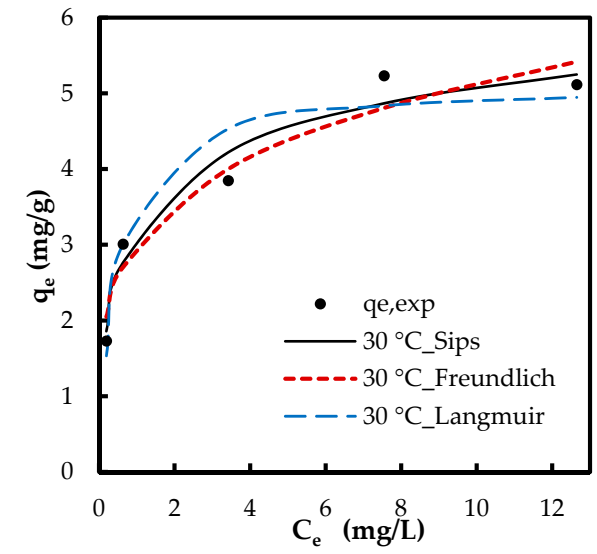

(c)

Figure 10. Experimental $q_{e}$ (markers) and theoretical $q_{e}$ (lines) via nonlinear regression of isotherm models at: (a) $20^{\circ} \mathrm{C}$; (b) $25^{\circ} \mathrm{C}$; and (c) $30^{\circ} \mathrm{C}$.

\subsubsection{Adsorption Thermodynamics}

The adsorption thermodynamics, the change of Gibb's free energy $(\Delta G)$, the change of entropy $(\Delta S)$, and the change in enthalpy $(\Delta H)[38]$ are defined by:

$$
\begin{aligned}
& \Delta G=-R T \ln K_{0} \\
& \Delta G=\Delta H-T \Delta S
\end{aligned}
$$

where $R$ is the universal gas constant $(8.314 \mathrm{~J} / \mathrm{K} \cdot \mathrm{mol}), T(\mathrm{~K})$ the temperature, and $K_{0}$ the unitless thermodynamic equilibrium constant [39]. The $K_{0}$ is extrapolated from the plot of $\ln \left(q_{e} / C_{e}\right)$ versus $C_{e}$ (Figure S4) [39]. The thermodynamic parameters are tabulated in Table 4.

The negative values of $\Delta G$ indicate the spontaneous adsorption of phosphate onto $\mathrm{Zn}$ (II)-CTS. Table 4 shows the negative value of $\Delta G$ increases with decreasing temperature, which is consistent with the isotherm results showing a more favorable adsorption at lower temperatures. The negative enthalpy change confirms the exothermic characteristic of adsorption. The heat evolved in the adsorption reveals the physical and chemical nature of the reaction. The value of $\Delta H(-37.86 \mathrm{~kJ} / \mathrm{mol})$ suggests the phosphate adsorption onto $\mathrm{Zn}(\mathrm{II})-\mathrm{CTS}$ is a physicochemical process rather than a purely physical or chemical adsorption [26,40]. The negative $\Delta S$ indicates the randomness decreases at the adsorption interface. Similar results have been reported in previous studies [41,42]. Worch [38] argues that a negative change in entropy is caused by the immobilization of adsorbate in the system. It can also indicate the fast adsorption of phosphate on the adsorptive sites [41]. 
Table 4. Calculated thermodynamic parameters.

\begin{tabular}{cccc}
\hline $\boldsymbol{T}(\mathrm{K})$ & $\boldsymbol{\Delta G} \mathbf{( \mathrm { kJ } / \mathrm { mol } )}$ & $\boldsymbol{\Delta H} \mathbf{( \mathrm { kJ } / \mathrm { mol } )}$ & $\boldsymbol{\Delta S}(\mathrm{J} / \mathrm{K} \cdot \mathbf{m o l})$ \\
\hline 293 & -5.27 & -37.86 & -111.32 \\
298 & -4.60 & & \\
303 & -4.15 & & \\
\hline
\end{tabular}

\subsubsection{Effect of Coexisting Ions}

Natural waters usually contain other anions competing for the adsorptive sites with phosphate. The competing effect of coexisting anions on phosphate adsorption by the developed bio-sorbent was studied with $\mathrm{NO}_{3}{ }^{-}, \mathrm{SO}_{4}{ }^{2-}$ and $\mathrm{Cl}^{-}$ions. Of these ions, chloride showed a minor effect, while nitrate and sulfate showed competing effect on the adsorption of phosphate (Figure 11). The equilibrium capacity of the bio-sorbent for phosphate in the absence of other ions was $7.63 \mathrm{mg} / \mathrm{g}$ while the phosphate adsorption in the presence of $\mathrm{NO}_{3}{ }^{-}, \mathrm{SO}_{4}{ }^{2-}$ and $\mathrm{Cl}^{-}$were $4.26,4.79$ and $7.15 \mathrm{mg} / \mathrm{g}$, respectively. These results agree with previously reported studies on phosphate adsorption $[3,4]$. The sensitivity of the phosphate adsorption to the presence of background ions, e.g., $\mathrm{SO}_{4}{ }^{2-}$ and $\mathrm{NO}_{3}{ }^{-}$, can indicate the outer-sphere complexation of phosphate with the bio-sorbent. Liu and Zhang [3] reported a notable reduction in phosphate uptake by modified chitosan beads in the presence of $\mathrm{SO}_{4}{ }^{2-}$, while $\mathrm{Cl}^{-}$and $\mathrm{NO}_{3}{ }^{-}$slightly reduced phosphate adsorption. It was explained that $\mathrm{SO}_{4}{ }^{2-}$ ions could more likely link with the functional groups on the surface of the composite, which in turn reduced the available active sites and hindered phosphate uptake. In addition, the accumulation of sulfate ions on the surface of the composite could contribute in forming a negatively charged surface, leading to an increasing repulsive force against phosphate oxyanions and hence a decreasing phosphate uptake. In the case of competing effect of nitrate, Seliem et al. [6] reported that the presence of $\mathrm{NO}_{3}{ }^{-}$significantly reduced the phosphate adsorption onto the composite of MCM-41 silica with rice husk and they attributed this effect to the initial $\mathrm{pH}$ of the solutions ( $\mathrm{pH}$ 9.56). Their study showed that by maintaining a constant $\mathrm{pH}$ of 6 , no obvious shift was noticed in the removal of phosphate, especially in the presence of nitrate molecules. Herein the nitrate molecules might hinder the adsorption of phosphate through mechanisms including the accumulation of nitrate anions on the surface of $\mathrm{Zn}$ (II)-CTS and formation of a negatively charged surface. Based on the results observed in this study and those previously reported, it can be inferred that: (I) The binding affinity of these ions for the adsorptive sites of the developed bio-sorbent are comparable with those of phosphate. (II) These ions can compete with phosphate for the adsorptive sites. (III) The mechanisms involved in the adsorption of phosphate and the other two ions onto the developed bio-sorbent are similar [43].

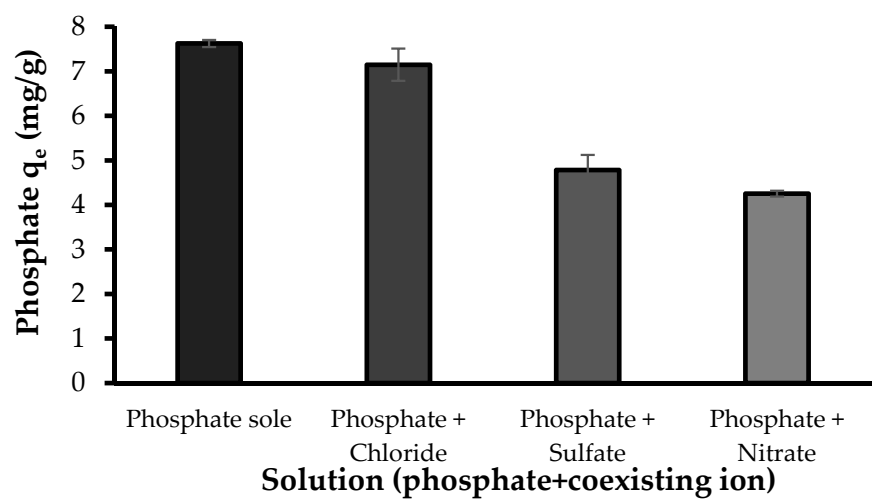

Figure 11. The effect of coexisting ions on phosphate adsorption (Experimental conditions: $5 \mathrm{mg} / \mathrm{L}$ phosphate concentration; $5 \mathrm{mg} / \mathrm{L}$ coexisting ion concentration; $0.5 \mathrm{~g} / \mathrm{L} \mathrm{Zn(II)-CTS} \mathrm{dose;} \mathrm{pH} 4$; 24 contact time). 


\subsection{Mechanisms of Zn(II)-CTS Complexation and Phosphate Adsorption}

CTS provided limited affinity for the oxyanions of phosphate as showed in Figure 4, which can be due to the $\mathrm{p} K_{\mathrm{a}}$ values of its electron-donating groups. Metal cations, e.g., $\mathrm{Zn}(\mathrm{II})$, however, are able to bind to CTS at different electron-donating sites, e.g., amine $-\mathrm{NH}_{2}$, on its chain. The complexed metal ion can then coordinate other ligands, providing adsorptive sites for phosphate on the CTS matrix that previously were unavailable, which is confirmed with the results presented in Figure 4. The mechanisms of metal ions complexation with CTS can be categorized in two categories of: (I) monodentate pattern; and (II) bidendate pattern [12,20]. In the former mechanism (I), the metal ions bind to one functional groups on CTS chain, while in the latter type (II) the metal ions bind to two or more functional groups, e.g., amino and hydroxyl groups, on one or more CTS chains so that act as a bridge between the chains [20]. Wang et al. [20] developed Zn(II)-CTS complexes for antibacterial application and noted that the complexes prepared with different zinc/CTS ratios were found to coordinate different amount of the metal ion and indicated diverse characteristics. The importance of $\mathrm{pH}$ and metal ion/CTS ratio in coordinating the metal ions on CTS structure was also reported for the $\mathrm{Cu}$ (II)-CTS complexes. Large $\mathrm{Cu}$ (II) loading changes the complexation mechanism from solely type (I) to a combination of types (I) and (II). It was also reported that the $\mathrm{pH}$ range $<\sim 5.5$ mainly led to the formation of type (I) and exceeding $\mathrm{pH}$ values created more of type (II) [44]. The formation of metal ion-CTS complexation can be explained through Lewis acid-base theory, where the metal ion $\left(\mathrm{M}^{2+}\right)$ plays the role of the acid by accepting the electron pairs provided by CTS as the base. The reaction equations are written as follows:

$$
\begin{gathered}
\text { CTS }-\mathrm{NH}_{2}+\mathrm{H}_{3} \mathrm{O}^{+} \rightarrow \mathrm{CTS}-\mathrm{NH}_{3}{ }^{+}+\mathrm{H}_{2} \mathrm{O} \\
\mathrm{CTS}-\mathrm{NH}_{3}{ }^{+}+\mathrm{M}^{\mathrm{n}+}+\mathrm{H}_{2} \mathrm{O} \rightarrow\left(\mathrm{CTS}-\mathrm{NH}_{2}-\mathrm{M}\right)^{\mathrm{n}+}+\mathrm{H}^{+}+\mathrm{H}_{2} \mathrm{O}
\end{gathered}
$$

where $\left(\mathrm{CTS}-\mathrm{NH}_{2}-\mathrm{M}\right)^{\mathrm{n}+}$ represents the metal ion-CTS complexes. Herein, $\mathrm{M}^{\mathrm{n}+}$ is $\mathrm{Zn}^{2+}(\mathrm{Zn}(\mathrm{II}))$. The FT-IR analysis showed that the $-\mathrm{NH}_{2}$ and $-\mathrm{OH}$ functional groups of CTS are involved in the complexation of CTS with Zn(II) in the bio-sorbent. The potential molecular structures of Zn(II)-CTS complexation are depicted in Figure 12.
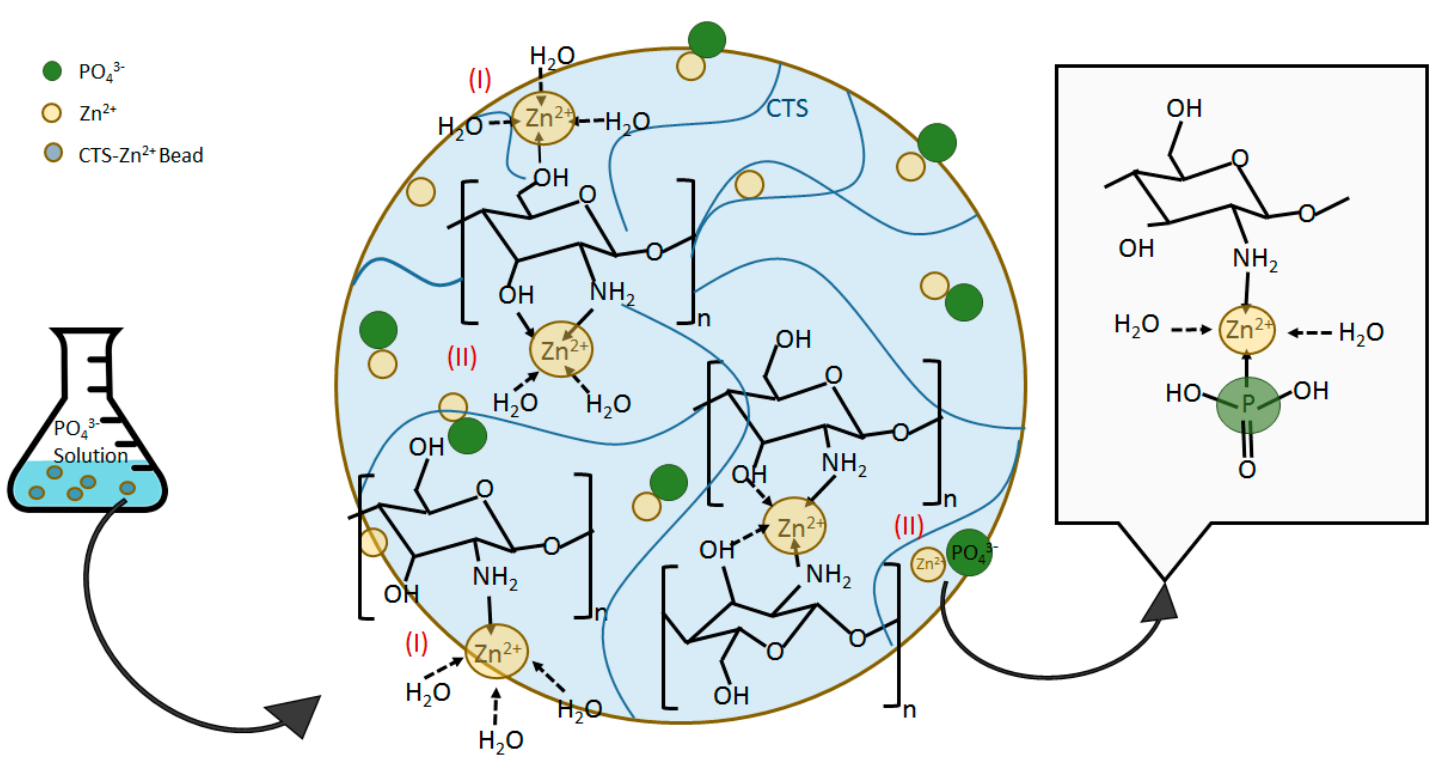

Figure 12. Possible structures of $\mathrm{Zn}(\mathrm{II})-\mathrm{CTS}$ complexation and corresponding mechanism for phosphate uptake. 
The type (I) complexation has been reported as the main mechanism favoring the uptake of phosphate $\mathrm{Cu}$ (II)-CTS complexes [12]. Some extent of phosphate uptake might also occur through the type (II) mechanism, yet, the magnitude of this uptake is minor in comparison with those of type (I) [12]. One explanation for this preference may lie in electrostatic interactions: electrons are more likely in a "diffused state" in complexation type (II) as they are distributed between different monomers and chains of CTS, whereas, in complexation type (I), electrons are configured in a more "concentrated state" so that electrostatic forces are strong enough to attract phosphate anions [12,45]. Besides, the involvement of two CTS chains in complexation type (II) may obstruct phosphate from adsorbing. Accordingly, the mechanism of phosphate uptake by the $\mathrm{Zn}$ (II)-CTS bio-sorbent proposed here is illustrated in Figure 12.

\subsection{Evaluation of Zn(II)-CTS Bio-Sorbent}

The adsorption capacities achieved by Zn(II)-CTS are compared with those of earlier reports on engineered adsorbents including zirconium-modified chitosan (ZCB) [3], zinc ferrite [46], magnetic iron oxide nanoparticles [47], $\mathrm{ZnCl}_{2}$-activated carbon [48], titanium dioxide [49], synthetic iron oxide coated sand [50] and magnetic illite clay [51], which are compiled in Table 5. The adsorption capacity of $\mathrm{Zn}(\mathrm{II})-\mathrm{CTS}$ was superior or comparable to the other adsorbents. For instance, magnetic iron, $\mathrm{ZnCl}_{2}$-activated carbon, zinc ferrite, and synthetic iron oxide coated sand provided lower maximum adsorption capacities compared with those of observed in the present study. When comparing different adsorbents studied for phosphate removal, the differences in operational conditions need to be taken into account. Unlike the studies conducted with higher phosphate concentrations, e.g., ZCB (Table 5), Zn(II)-CTS was studied with relatively lower, yet, more environmentally relevant phosphate concentrations, which most likely explains the difference in maximum capacities.

Table 5. Phosphate adsorption on different engineered adsorbents.

\begin{tabular}{ccccc}
\hline Adsorbent & $\boldsymbol{C}_{\mathbf{0}}(\mathbf{m g} / \mathbf{L})$ & $\boldsymbol{q}_{\text {max }}(\mathbf{m g} / \mathbf{g})$ & $\mathbf{p H}$ & Reference \\
\hline Zn(II)-CTS & 5 & 7.37 & 4 & Present \\
Zn(II)-CTS & 5 & 6.3 & natural & Present \\
Chitosan & 5 & 1.45 & natural & Present \\
Chitosan & 5 & 4.75 & 4 & Present \\
Naturally iron oxide coated sand & $5-30$ & 0.88 & 5 & {$[50]$} \\
Synthetic iron oxide coated sand & $5-30$ & 1.50 & 5 & {$[50]$} \\
Zinc ferrite & 5 & 5.23 & - & {$[46]$} \\
Magnetic illite clay & $10-100$ & 5.48 & - & {$[51]$} \\
ZCB & $5-50$ & 60.60 & 4 & {$[3]$} \\
Quaternized chitosan beads & 1000 & 59.00 & - & {$[5]$} \\
TiOO & - & 2.63 & 5 & {$[49]$} \\
ZnCl $_{2}$-carbon & 10 & 5.10 & - & {$[48]$} \\
Magnetic iron & $2-20$ & 5.03 & - & {$[47]$} \\
\hline
\end{tabular}

\section{Conclusions}

This study developed zinc(II)-chitosan bio-sorbents for phosphate removal from aqueous solution. The effect of operational parameters, e.g., $\mathrm{pH}$, dose and contact time, on the adsorption phosphate by the complexes was explored in detail. The optimum dose of the bio-sorbent was found to be $0.5 \mathrm{mg} / \mathrm{L}$. It was observed that lower $\mathrm{pH}$ values favor the adsorption of phosphate. A rapid adsorption was observed within the first $3 \mathrm{~h}$ of contact time for all three studied concentrations. The temperature study revealed that the adsorption process was more successful in lower temperatures and it was exothermic and spontaneous in nature. The study of co-existing ions revealed that $\mathrm{Cl}^{-}$shows minor effect on phosphate removal, whereas $\mathrm{NO}_{3}{ }^{-}$and $\mathrm{SO}_{4}{ }^{2-}$ show competing effect. Pseudo-second-order model was more applicable to kinetics study. The intra-particle diffusion study revealed that at least two steps were involved in the adsorption process, the boundary layer stage and the intra-particle diffusion 
stage. The adsorption isotherm was well fitted with Freundlich and Sips isotherms. CTS is a unique adsorbent, a completely natural and biodegradable polymer. Along with studies on the antimicrobial activity, thermal degradation, and pyrolysis characteristics of CTS complexes with zinc(II) [20,21], this study provides deeper understanding of the zinc(II)-CTS as a bio-sorbent for more accurate application towards specific target, e.g., phosphate removal.

Supplementary Materials: The following are available online at www.mdpi.com/2073-4360/10/1/25/s1, Figure S1: The linear plot of $t / q_{t}$ versus $t$ for the determination of psodo-second-order kinetic model parameters via linear regression. Figure S2: (a) Theoretical $q_{t}$ (lines) by pseudo-first-order kinetic model; and (b) theoretical $q_{t}$ (lines) by pseudo-second-order kinetic model compared to experimental $q_{t}$ (markers). Figure S3: (a) Theoretical values of $q_{e}$ (lines) from Langmuir isotherm model; and (b) theoretical values of $q_{e}$ (lines) from Freundlich isotherm model compared to experimental $q_{e}$ (markers). Figure S4: The plot of $\ln \left(q_{e} / C_{e}\right)$ versus $C_{e}$ for determination of $K_{0}$.

Acknowledgments: This work was conducted at Aalto University's analytical water laboratory. The electron microscopy was carried out at Aalto University's nanomicroscopy center. The research was funded by the MVTT organization (Maa- ja vesitekniikan tuki) (grant reference number 32900), which is gratefully acknowledged. The first author would like to thank the Doctoral School of Aalto University and Foundation for Aalto University Science and Technology for their financial support. The authors would like to acknowledge Laboratory Manager Ari Järvinen, Senior Laboratory Technician Aino Peltola and Laboratory Technician Marina Sushko, Aalto University, for their helps and fast phosphate measurements. We would also like to thank Maryam Borghei, Bio-based Colloids and Materials Group-Aalto University, for the assistance with the intrinsic viscosity measurements and Taneli Tiittanen, Inorganic Chemistry Laboratory-Aalto University, for conducting the FT-IR analysis. Sincere acknowledgement to three anonymous reviewers for their valuable comments towards improvement of this work.

Author Contributions: Maryam Roza Yazdani planned the research, designed the study, and instructed the experiments. Elina Virolainen performed the experiments. Maryam Roza Yazdani, Elina Virolainen, and Kevin Conley analyzed the data and wrote the paper. Riku Vahala reviewed and commented on the paper.

Conflicts of Interest: The authors declare no conflict of interest.

\section{References}

1. Conley, D.J.; Paerl, H.W.; Howarth, R.W.; Boesch, D.F.; Seitzinge, S.P.; Havens, K.E.; Lancelot, C.; Likens, G.E. Controlling eutrophication: Nitrogen and phosphorus. Sci. Total Environ. 2009, 323, 1014-1015. [CrossRef] [PubMed]

2. Morse, G.K.; Brett, S.W.; Guy, J.A.; Lester, J.N. Review: Phosphorus removal and recovery technologies. Sci. Total Environ. 1998, 212, 69-81. [CrossRef]

3. Liu, X.; Zhang, L. Removal of phosphate anions using the modified chitosan beads: Adsorption kinetic, isotherm and mechanism studies. Powder Technol. 2015, 277, 112-119. [CrossRef]

4. Ding, L.; Wu, C.; Deng, H.; Zhang, X. Adsorptive characteristics of phosphate from aqueous solutions by miex resin. J. Colloid Interface Sci. 2012, 376, 224-232. [CrossRef] [PubMed]

5. Sowmya, A.; Meenakshi, S. An efficient and regenerable quaternary amine modified chitosan beads for the removal of nitrate and phosphate anions. J. Environ. Chem. Eng. 2013, 1, 906-915. [CrossRef]

6. Seliem, M.K.; Komarneni, S.; Abu Khadra, M.R. Phosphate removal from solution by composite of MCM-41 silica with rice husk: Kinetic and equilibrium studies. Microporous Mesoporous Mater. 2016, 224, 51-57. [CrossRef]

7. Lalley, J.; Han, C.; Li, X.; Dionysiou, D.D.; Nadagouda, M.N. Phosphate adsorption using modified iron oxide-based sorbents in lake water: Kinetics, equilibrium, and column tests. Chem. Eng. J. 2016, 284, 1386-1396. [CrossRef]

8. Miettinen, I.T.; Vartiainen, T.; Martikainen, P.J. Phosphorus and bacterial growth in drinking water. Appl. Environ. Microbiol. 1997, 63, 3242-3245. [PubMed]

9. U.S. Environmental Protection Agency (USEPA). Quality Criteria for Water; EPA 440/5-86-001; Office of Water Regulation and Standard: Washington, DC, USA, 1986.

10. De-Bashan, L.E.; Bashan, Y. Recent advances in removing phosphorus from wastewater and its future use as fertilizer (1997-2003). Water Res. 2004, 38, 4222-4246. [CrossRef] [PubMed]

11. Awual, M.R.; Jyo, A.; Ihara, T.; Seko, N.; Tamada, M.; Lim, K.T. Enhanced trace phosphate removal from water by zirconium(IV) loaded fibrous adsorbent. Water Res. 2011, 45, 4592-4600. [CrossRef] [PubMed] 
12. Yamani, J.S.; Lounsbury, A.W.; Zimmerman, J.B. Towards a selective adsorbent for arsenate and selenite in the presence of phosphate: Assessment of adsorption efficiency, mechanism, and binary separation factors of the chitosan-copper complex. Water Res. 2016, 88, 889-896. [CrossRef] [PubMed]

13. Wan Ngah, W.S.; Teong, L.C.; Hanafiah, M.A.K.M. Adsorption of dyes and heavy metal ions by chitosan composites: A review. Carbohydr. Polym. 2011, 83, 1446-1456. [CrossRef]

14. Madill, E.A.W.; Garcia-Valdez, O.; Champagne, P.; Cunningham, M.F. $\mathrm{CO}_{2}$-responsive graft modified chitosan for heavy metal (nickel) recovery. Polymers 2017, 9, 39. [CrossRef]

15. Yazdani, M.R.; Bhatnagar, A.; Vahala, R. Synthesis, characterization and exploitation of nano- $\mathrm{TiO}_{2} / \mathrm{feldspar}$ embedded chitosan beads towards UV-assisted adsorptive abatement of aqueous arsenic (As). Chem. Eng. J. 2017, 316, 370-382. [CrossRef]

16. Prabhu, S.M.; Meenakshi, S. A dendrimer-like hyper branched chitosan beads toward fluoride adsorption from water. Int. J. Biol. Macromol. 2015, 78, 280-286. [CrossRef] [PubMed]

17. Yazdani, M.; Bahrami, H.; Arami, M. Feldspar/titanium dioxide/chitosan as a biophotocatalyst hybrid for the removal of organic dyes from aquatic phases. J. Appl. Polym. Sci. 2014, 131, 40247-40256. [CrossRef]

18. Mahaninia, M.H.; Wilson, L.D. Cross-linked chitosan beads for phosphate removal from aqueous solution. J. Appl. Polym. Sci. 2016, 133. [CrossRef]

19. Cao, J.; Cao, H.; Zhu, Y.; Wang, S.; Qian, D.; Chen, G.; Sun, M.; Huang, W. Rapid and effective removal of $\mathrm{Cu}^{2+}$ from aqueous solution using novel chitosan and laponite-based nanocomposite as adsorbent. Polymers 2017, 9, 5. [CrossRef]

20. Wang, X.; Du, Y.; Liu, H. Preparation, characterization and antimicrobial activity of chitosan-Zn complex. Carbohydr. Polym. 2004, 56, 21-26. [CrossRef]

21. Ou, C.; Chen, S.; Liu, Y.; Shao, J.; Li, S.; Fu, T.; Fan, W.; Zheng, H.; Lu, Q.; Bi, X. Study on the thermal degradation kinetics and pyrolysis characteristics of chitosan-Zn complex. J. Anal. Appl. Pyrolysis 2016, 122, 268-276. [CrossRef]

22. Yuan, Y.; Chesnutt, B.M.; Haggard, W.O.; Bumgardner, J.D. Deacetylation of chitosan: Material characterization and in vitro evaluation via albumin adsorption and pre-osteoblastic cell cultures. Materials 2011, 4, 1399-1416. [CrossRef] [PubMed]

23. Jia, Z.; Shen, D. Effect of reaction temperature and reaction time on the preparation of low-molecular-weight chitosan using phosphoric acid. Carbohydr. Polym. 2002, 49, 393-396. [CrossRef]

24. Kasaai, M.R. Calculation of Mark-Houwink-Sakurada (MHS) equation viscometric constants for chitosan in any solvent-temperature system using experimental reported viscometric constants data. Carbohydr. Polym. 2007, 68, 477-788. [CrossRef]

25. Costa, C.N.; Teixeira, V.G.; Delpech, M.C.; Souza, J.V.S.; Costa, M.A.S. Viscometric study of chitosan solutions in acetic acid/sodium acetate and acetic acid/sodium chloride. Carbohydr. Polym. 2015, 133, 245-250. [CrossRef] [PubMed]

26. Yazdani, M.R.; Tuutijärvi, T.; Bhatnagar, A.; Vahala, R. Adsorptive removal of arsenic(V) from aqueous phase by feldspars: Kinetics, mechanism, and thermodynamic aspects of adsorption. J. Mol. Liq. 2016, 214, 149-156. [CrossRef]

27. Anandhavelu, S.; Thambidurai, S. Preparation of chitosan-zinc oxide complex during chitin deacetylation. Carbohydr. Polym. 2011, 83, 1565-1569. [CrossRef]

28. Pandiselvi, K.; Thambidurai, S. Synthesis of porous chitosan-polyaniline/ZnO hybrid composite and application for removal of reactive orange 16 dye. Colloids Surf. B Biointerfaces 2013, 108, 229-238.

29. Lagergren, S. About the theory of so-called adsorption of soluble substances. Kungliga Sven. Vetenskapsakademiens Handl. 1898, 24, 1-39.

30. Ho, Y.S.; McKay, G. Pseudo-second order model for sorption processes. Process Biochem. 1999, 34, 451-465. [CrossRef]

31. Shi, X.; Li, Q.; Wang, T.; Lackner, K.S. Kinetic analysis of an anion exchange absorbent for $\mathrm{CO}_{2}$ capture from ambient air. PLoS ONE 2017, 12, e0179828. [CrossRef] [PubMed]

32. Su, Y.; Yang, W.; Sun, W.; Li, Q.; Shang, J.K. Synthesis of mesoporous cerium-zirconium binary oxide nanoadsorbents by a solvothermal process and their effective adsorption of phosphate from water. Chem. Eng. J. 2015, 268, 270-279. [CrossRef]

33. Weber, W.J.; Morris, J.C. Kinetics of adsorption on carbon from solution. J. Sanit. Eng. Div. Proc. Am. Soc. Civ. Eng. 1963, 89, 31-60. 
34. Lin, K.A.; Liu, Y.; Chen, S. Adsorption of fluoride to UiO-66- $\mathrm{NH}_{2}$ in water: Stability, kinetic, isotherm and thermodynamic studies. J. Colloid Interface Sci. 2016, 461, 79-87. [CrossRef] [PubMed]

35. Cheung, W.H.; Szeto, Y.S.; McKay, G. Intraparticle diffusion processes during acid dye adsorption onto chitosan. Bioresour. Technol. 2007, 98, 2897-2904. [CrossRef] [PubMed]

36. Liu, Q.; Hu, P.; Wang, J.; Zhang, L.; Huang, R. Phosphate adsorption from aqueous solutions by zirconium (IV) loaded cross-linked chitosan particles. J. Taiwan Inst. Chem. Eng. 2016, 59, 311-319. [CrossRef]

37. Giles, C.H.; Smith, D.; Huitson, A. A general treatment and classification of the solute adsorption isotherm. I. Theoretical. J. Colloid Interface Sci. 1974, 47, 755-765. [CrossRef]

38. Worch, E. Adsorption Technology in Water Treatment: Fundamentals, Processes, and Modeling; Walter de Gruyter: Munchen, Germany, 2012.

39. Demirbas, A.; Sari, A.; Isildak, O. Adsorption thermodynamics of stearic acid onto bentonite. J. Hazard. Mater. 2006, 135, 226-231. [CrossRef] [PubMed]

40. Smith, J.M. Chemical Engineering Kinetics, 3rd ed.; McGraw-Hill: New York, NY, USA, 1981.

41. Raji, F.; Pakizeh, M. Kinetic and thermodynamic studies of $\mathrm{Hg}$ (II) adsorption onto MCM-41 modified by $\mathrm{ZnCl}_{2}$. Appl. Surf. Sci. 2014, 301, 568-575. [CrossRef]

42. Tan, Z.; Peng, H.; Liu, H.; Wang, L.; Chen, J.; Lu, X. Facile preparation of EDTA-functionalized chitosan magnetic adsorbent for removal of $\mathrm{Pb}(\mathrm{II})$. J. Appl. Polym. Sci. 2015, 132. [CrossRef]

43. Guan, X.; Dong, H.; Ma, J.; Jiang, L. Removal of arsenic from water: Effects of competing anions on As(III) removal in $\mathrm{KMnO}_{4}-\mathrm{Fe}(\mathrm{II})$ process. Water Res. 2009, 43, 3891-3899. [CrossRef] [PubMed]

44. Rhazi, M.; Desbrières, J.; Tolaimate, A.; Rinaudo, M.; Vottero, P.; Alagui, A. Contribution to the study of the complexation of copper by chitosan and oligomers. Polymer 2001, 43, 1267-1276. [CrossRef]

45. Shi, X.; Xiao, H.; Chen, X.; Lackner, K.S. The effect of moisture on the hydrolysis of basic salts. Chem. Eur. J. 2016, 22, 18326-18330. [CrossRef] [PubMed]

46. Gu, W.; Xie, Q.; Qi, C.; Zhao, L.; Wu, D. Phosphate removal using zinc ferrite synthesized through a facile solvothermal technique. Powder Technol. 2016, 301, 723-729. [CrossRef]

47. Yoon, S.-Y.; Lee, C.-G.; Park, J.-A.; Kim, J.-H.; Kim, S.-B.; Lee, S.-H.; Choi, J.-W. Kinetic, equilibrium and thermodynamic studies for phosphate adsorption to magnetic iron oxide nanoparticles. Chem. Eng. J. 2014, 236, 341-347. [CrossRef]

48. Namasivayam, C.; Sangeetha, D. Equilibrium and kinetic studies of adsorption of phosphate onto $\mathrm{ZnCl}_{2}$ activated coir pith carbon. J. Colloid Interface Sci. 2004, 280, 359-365. [CrossRef] [PubMed]

49. Darcy, M.; Weiss, D.; Bluck, M.; Vilar, R. Adsorption kinetics, capacity and mechanism of arsenate and phosphate on a bifunctional $\mathrm{TiO}_{2}-\mathrm{Fe}_{2} \mathrm{O}_{3}$ bi-composite. J. Colloid Interface Sci. 2011, 364, 205-212. [CrossRef] [PubMed]

50. Boujelben, N.; Bouzid, J.; Elouear, Z.; Feki, M.; Jamoussi, F.; Montiel, A. Phosphorus removal from aqueous solution using iron coated natural and engineered sorbents. J. Hazard. Mater. 2008, 151, 103-110. [CrossRef] [PubMed]

51. Chen, J.; Yan, L.; Yu, H.; Li, S.; Qin, L.; Liu, G.; Li, Y.; Du, B. Efficient removal of phosphate by facile prepared magnetic diatomite and illite clay from aqueous solution. Chem. Eng. J. 2016, 287, 162-172. [CrossRef]

(C) 2017 by the authors. Licensee MDPI, Basel, Switzerland. This article is an open access article distributed under the terms and conditions of the Creative Commons Attribution (CC BY) license (http://creativecommons.org/licenses/by/4.0/). 